\title{
Carbohydrate Level, Photosynthesis, and Respiration in Creeping Bentgrass as Influenced by Spring and Summer Coring
}

\author{
Jinmin Fu and Peter H. Dernoeden ${ }^{1}$ \\ Department of Plant Science and Landscape Architecture, University of Maryland, College Park, \\ MD 20742
}

\begin{abstract}
AdDitional INDEX wORDs. Agrostis stolonifera, water soluble carbohydrates, storage, leaves, roots
Abstract. Carbohydrates provide energy required to maintain healthy plant growth in summer. Coring is performed periodically on creeping bentgrass (Agrostis stolonifera L.) putting greens for numerous reasons; however, its impact on carbohydrate metabolism in creeping bentgrass is unknown. The objectives of this 2-year field study were to examine the effects of coring on rates of photosynthesis $\left(P_{n}\right)$ and whole plant respiration $\left(R_{w}\right)$, and to quantify watersoluble carbohydrates [WSC (i.e., glucose, fructose, and sucrose)], storage carbohydrates [SC (i.e., fructan and starch], and total nonstructural carbohydrates [TNC (i.e., WSC + SC)] in creeping bentgrass leaves and roots during the summer. The study site was 'Providence' creeping bentgrass grown on a sand-based root zone and was maintained as a putting green. Three coring treatments were assessed as follows: spring-only coring, spring plus three summer corings, and a noncored control. $P_{n}$ and $R_{w}$ were measured about $21 \mathrm{~d}$ following coring with hollow tines. $P_{n}$ and $R_{w}$ rates generally were similar among all three coring treatments in both years. Hence, summer coring had no apparent negative impact on $P_{n}$ or $R_{w}$. Leaf and root WSC, SC, and TNC levels were similar among coring treatments throughout the summer of each year. However, root TNC levels were lower in July of each year in spring plus summer-cored bentgrass versus other coring treatments. By September, leaves and roots from spring plus summercored creeping bentgrass had higher TNC levels when compared with spring-only or noncored bentgrass. Leaf and root SC levels from spring plus summer-cored bentgrass were also higher in September than were observed in noncored bentgrass. Spring plus summer coring benefited creeping bentgrass by promoting an accumulation of carbohydrates in late summer, which could assist plants in their recovery from summer stresses.
\end{abstract}

Core cultivation or coring is routinely performed on putting greens for a multitude of beneficial purposes as outlined by McCarty (2001). However, coring is disruptive to the putting surface and causes mechanical injury to turf. Mechanical injury to plants would be expected to result in an increase in respiration and possibly a reduction in photosynthesis. A concomitant decrease in photosynthesis and increase in respiration could cause a harmful depletion of carbohydrates. Few studies have been performed that investigated the impact of mechanical injury on carbon metabolism in turfgrasses. However, Howieson and Christians (2008) investigated the effect of rolling and mowing (single and double cutting) on carbohydrate metabolism in creeping bentgrass grown in a greenhouse. They found that fructan levels in leaves were reduced in single- and double-cut creeping bentgrass compared with uncut plants by $52 \%$ and $45 \%$, respectively. Glucose levels were reduced $31 \%$ in double-cut creeping bentgrass compared with uncut bentgrass (Howieson and Christians, 2008). However, leaf fructan levels in creeping bentgrass subjected to the two mowing practices reached the same level as that of uncut plants at 60 $\mathrm{h}$ following mowing (Howieson and Christians, 2008).

The rate of turf recovery from mechanical injury can depend on the availability of carbohydrates (Donaghy and Fulkerson, 1998). Carbohydrates in turfgrasses consist of the monosaccharides, glucose and fructose (reducing sugars), disaccharide

Received for publication 16 June 2008. Accepted for publication 18 Nov. 2008. We are grateful for financial support from the U.S. Golf Association.

This publication is a contribution of the Maryland Agricultural Experiment Station.

We thank Dr. Theophanes Solomos for providing laboratory support for this investigation.

${ }^{1}$ Corresponding author. E-mail: pd@umd.edu. sucrose, and various starches and fructans (Smith, 1972). Fructan can be hydrolyzed into fructose, which can be converted to glucose or used to form sucrose. Mono- and disaccharides are depleted during respiration, when new leaves and roots of perennial ryegrass (Lolium perenne L.) are produced (Amiard et al., 2003). Root growth in some grasses is more sensitive to a decrease in the availability of carbohydrates than leaf growth (Donaghy and Fulkerson, 1998). Therefore, root regrowth following coring may require a considerable amount of carbon investment.

Understanding how leaf and root carbohydrate levels change following coring may be important for maintaining highquality creeping bentgrass greens. This is especially true in summer when high temperature stress reduces photosynthesis, root growth, and quality in creeping bentgrass (Xu and Huang, 2000). As previously noted, the effects of coring on carbohydrate metabolism during summer months in creeping bentgrass has not been documented. Therefore, the objectives of this field study were to quantify rates of photosynthesis $\left(\mathrm{P}_{\mathrm{n}}\right)$ and whole plant respiration $\left(\mathrm{R}_{\mathrm{w}}\right)$ rates as well as carbohydrate levels [i.e., water-soluble carbohydrates (WSC), storage carbohydrates (SC), and total nonstructural carbohydrates (TNC)] in creeping bentgrass leaves and roots in response to spring-only coring versus spring plus summer coring.

\section{Materials and Methods}

This field study was conducted on a research green built to U.S. Golf Association (2004) recommendations at the University of Maryland Turfgrass Research Facility in College Park in 2006 and 2007. Soil was a modified sand mix (97\% sand, 1\% 
silt, and $2 \%$ clay) with a $\mathrm{pH}$ of 6.5 and $10 \mathrm{mg}$ of organic matter per gram of soil. In Sept. 2005, the study site was treated with glyphosate and the sod was removed to expose bare ground. The area was seeded (50 kg.ha ${ }^{-1}$ seed) with 'Providence' creeping bentgrass in Sept. 2005. Turf was fertilized $\left(25 \mathrm{~kg} \cdot \mathrm{ha}^{-1}\right.$ $\left.\mathrm{N}+11 \mathrm{~kg} \cdot \mathrm{ha}^{-1} \mathrm{P}+20 \mathrm{~kg} \cdot \mathrm{ha}^{-1} \mathrm{~K}\right)$ eight times $(20,23,28$, and 30 Sept.; 18 and 20 Oct.; and 1 and 3 Nov.) in 2005 with a 20N8.7P-16.6K fertilizer. A $19 \mathrm{~N}-0.9 \mathrm{P}-15.8 \mathrm{~K}$ fertilizer was applied on $11 \mathrm{Nov}$. to provide $50 \mathrm{~kg} \cdot \mathrm{ha}^{-1} \mathrm{~N}, 2.3 \mathrm{~kg} \cdot \mathrm{ha}^{-1} \mathrm{P}$, and $40 \mathrm{~kg} \cdot \mathrm{ha}^{-1} \mathrm{~K}$. A total of $250 \mathrm{~kg} \cdot \mathrm{ha}^{-1} \mathrm{~N}$ was applied between 20 Sept. and 11 Nov. 2005. The bentgrass was fertilized biweekly with $4.9 \mathrm{~kg} \cdot \mathrm{ha}^{-1} \mathrm{~N}$ from urea between 1 May and 7 June and then weekly through 24 Aug. for a total of $78.4 \mathrm{~kg} \cdot \mathrm{ha}^{-1}$ $\mathrm{N}$ during the experimental period in 2006. In Autumn 2006, 71 $\mathrm{kg} \cdot \mathrm{ha}^{-1} \mathrm{~N}$ was applied between September and November. In 2007, the bentgrass was fertilized weekly with $4.9 \mathrm{~kg} \cdot \mathrm{ha}^{-1} \mathrm{~N}$ from urea between $30 \mathrm{Apr}$. and $27 \mathrm{Aug}$. to provide a total of $88.2 \mathrm{~kg} \cdot \mathrm{ha}^{-1} \mathrm{~N}$ during the experimental period.

Iprodione (14.7 kg.ha-1 a.i.) was applied biweekly from June through August in 2006 and 2007 to control dollar spot (Sclerotinia homoeocarpa F.T. Bennett) and brown patch (Rhizoctonia solani Kuhn). Iprodione was chosen because it has no known plant growth regulator effects. Deltamethrin $\left(2.2 \mathrm{~kg} \cdot \mathrm{ha}^{-1}\right.$ a.i.) was applied on 26 July and 24 Aug. 2006 and 18 July 2007 to control sod webworm (Pediasia trisecta Walker). Turf was mowed three times weekly to a height of $6 \mathrm{~mm}$ in Spring 2006. Mowing height was reduced to $4 \mathrm{~mm}$ on 3 July 2006; the green was mowed at that height thereafter about five times weekly and clippings were removed. Turf was irrigated to prevent wilt and was syringed frequently during dry, windy periods.

Three coring treatments were assessed as follows: noncored, spring-only coring, and spring plus summer coring. Each plot measured $1.8 \times 2.4 \mathrm{~m}$ and was separated by a $60-\mathrm{cm}$ creeping bentgrass perimeter border. Typically, large-diameter tines are used to core greens in the spring and small-diameter tines are used in the summer (O'Brien and Hartwiger, 2003). Larger tines are used in spring because turf generally can recover more rapidly from mechanical injury at this time versus the summer. In the spring coring program, plots were cored once annually on 27 Apr. 2006 and 29 Apr. 2007 using a Miltona Handi Aerifer (Miltona Turf Products, Miltona, MN). This hand-held, manual device had seven, $1.27-\mathrm{cm}$-diameter hollow tines that penetrated to a depth of $9.0 \mathrm{~cm}$. Cores were removed on $5.0-\mathrm{cm}$ spacings and there were about 400 holes $/ \mathrm{m}^{2}$. Spring plus summer treatment involved coring in April as previously described combined with three summer corings using hollow tines. Summer coring was performed using one leg taken from a CoreMaster *12 Aerator (GreenCare, Sydney, Australia) equipped with a quadra-tine holder on 6 and 28 June and 25 July 2006; and 6 June, and 3 and 31 July 2007. The four, 0.64-cmdiameter hollow tines penetrated to a depth of $5.5 \mathrm{~cm}$ on a right angle spacing of $3.8 \mathrm{~cm}$ and a diagonal spacing of $5.0 \mathrm{~cm}$. The quadra-tine leg was manually forced into the turf and about 690 holes $/ \mathrm{m}^{2}$ were made. Topdressing, using the previously described modified sand construction mix, followed spring coring to fill holes to the surface. Following summer coring, plots were brushed to incorporate sand from cores, but no additional topdressing sand was applied.

Canopy net photosynthesis and $\mathrm{R}_{\mathrm{w}}$, including plant and soil microbe respiration, were measured on a 2 - to 3 -week interval between 6 June and 7 Sept. 2006 and on a 3- to 4-week interval between 31 May and 6 Sept. 2007 using a portable gas exchange system (LI-6400; LI-COR, Lincoln, NE). Photosynthesis and $\mathrm{R}_{\mathrm{W}}$ were determined by enclosing the turf canopy $\left(126.6 \mathrm{~cm}^{2}\right)$ in a transparent Plexiglas chamber $(15 \times 10 \times 10$ $\mathrm{cm}$ ) attached to a LI-6400 $\mathrm{CO}_{2}$ analyzer (LI-COR) as described by $\mathrm{Fu}$ et al. (2007). When $\mathrm{R}_{\mathrm{w}}$ was measured, the transparent Plexiglas chamber was wrapped with a double layer of black plastic to prevent sunlight from entering the chamber. Measurements were taken on average $21 \mathrm{~d}$ (range of 9-33 d) following coring on clear sunny days between 1100 and 1400 HR. Final $P_{n}$ and $R_{w}$ measurements in September were taken 42 and $37 \mathrm{~d}$ following the last summer coring in 2006 and 2007, respectively. Measurements of $\mathrm{P}_{\mathrm{n}}$ and $\mathrm{R}_{\mathrm{w}}$ were obtained in one location of each plot on each date and data were expressed as $\mathrm{CO}_{2}$ uptake and evolution per unit area.

Clippings were the source of mostly leaf plus some sheath (hereafter leaf or leaves) tissue used to measure WSC and SC levels. Clippings were collected using a walk-behind reel mower equipped with a basket. Clippings were collected on 25 May, 21 June, 21 July, 4 Aug., and 7 Sept. 2006; and 1 and 28 June, 17 July, 15 Aug., and 6 Sept. 2007. Roots were sampled by removing four soil cores $(2.5 \mathrm{~cm}$ diameter $\times 20 \mathrm{~cm}$ deep) from each plot on the aforementioned dates. Green leaf tissue and the thatch-mat layer of each soil core were removed with scissors. The four soil cores from each plot were mixed, and roots were washed free of soil. Leaves and roots were put in separate plastic bags and placed immediately in liquid nitrogen and stored in a freezer at $-80{ }^{\circ} \mathrm{C}$ until analyzed. Frozen tissue samples were killed at $105^{\circ} \mathrm{C}$ for $30 \mathrm{~min}$, oven-dried at $70{ }^{\circ} \mathrm{C}$ until there was no further weight loss, ground in liquid nitrogen, and passed through a $0.4-\mathrm{mm}$ sieve. For analysis of WSC and $\mathrm{SC}, 50 \mathrm{mg}$ of dry tissue were placed in a $2.0-\mathrm{mL}$ microtube, extracted three times in $1.0 \mathrm{~mL}$ of $92 \%$ ethanol, vigorously shaken for $10 \mathrm{~min}$, and then centrifuged at 20,000 $g_{\mathrm{n}}$ for $10 \mathrm{~min}$ as described by Wang and Jiang (2007). The supernatant containing reducing sugars (i.e., glucose and fructose) and sucrose was collected in a $10-\mathrm{mL}$ test tube. The microtubes were left open and placed in an oven at $70{ }^{\circ} \mathrm{C}$ to evaporate the ethanol. The residue was used for $\mathrm{SC}$ analysis.

A 3-mL sample of combined supernatant containing glucose, fructose, and sucrose was diluted with distilled water to 10 $\mathrm{mL}$. A 2-mL sample of the diluted supernatant was transferred to a test tube with $2 \mathrm{~mL}$ of $4 \% \mathrm{H}_{2} \mathrm{SO}_{4}(\mathrm{w} / \mathrm{v})$, mixed, and boiled for $15 \mathrm{~min}$ to hydrolyze sucrose to reducing sugar (i.e., glucose and fructose). The solution then was neutralized with $1.0 \mathrm{~mL}$ of $1 \mathrm{~N} \mathrm{NaOH}$. Ferricyanide reagent and arsenomolybdate solution were used to quantify reducing sugars as described by Ting (1956). The above solution $(0.2 \mathrm{~mL})$ was transferred into a 20 $\mathrm{mL}$ volumetric tube and $0.8 \mathrm{~mL}$ of distilled water and $1.25 \mathrm{~mL}$ of ferricyanide reagent were added (Ting, 1956). The solution was boiled in a water bath for $10 \mathrm{~min}$ and then cooled in ice water. A $2.5-\mathrm{mL}$ aliquot of $2.0 \mathrm{M}$ sulfuric acid was added to partially neutralize the solution. After neutralization, the tube containing the solution was shaken until gas evolution ceased, and $1.0 \mathrm{~mL}$ of arsenomolybdate solution was added (Ting, 1956). The solution was again shaken and diluted with distilled water to volume $(20 \mathrm{~mL})$. The absorbance of the solution was measured at $515 \mathrm{~nm}\left(\mathrm{OD}_{515}\right)$ using a spectrophotometer (Beckman Coulter, Fullerton, CA). The amount of sugar in the solution was calculated using a glucose standard curve as described by Ting (1956). WSC, SC, and TNC levels were expressed as milligrams of glucose per gram dry weight. 
Fructan and starch, which were obtained from the previously described SC residue, were hydrolyzed into reducing sugars using the method described by Smith (1981). For quantifying fructan and starch, $0.5 \mathrm{~mL}$ of distilled water was added to each microtube containing the recovered residue (about $50 \mathrm{mg}$ ) after the extraction of WSC from ethanol. The microtubes were sealed and placed on a heating block at $100{ }^{\circ} \mathrm{C}$ for $10 \mathrm{~min}$, removed from the heating block, and cooled to room temperature. Then, $0.4 \mathrm{~mL}$ of $200 \mathrm{~mm}$ acetate buffer ( $\mathrm{pH} 5.1$ ) and $0.1 \mathrm{~mL}$ of enzyme solution were added to each microtube as described by Smith (1981). Final enzyme concentrations were 0.2 units of amyloglucosidase (product A 1602; Sigma, St. Louis) and 40 units of alphaamylase (product A 2643, Sigma) per microtube. The microtubes were sealed, vortexed, and incubated at $55^{\circ} \mathrm{C}$ for 16 to $24 \mathrm{~h}$. When incubation was completed, the tubes were centrifuged at $20,000 g_{\mathrm{n}}$ for $10 \mathrm{~min}$. The extract containing glucose (decomposed from starch) and fructan was diluted with distilled water 10 times $(1: 10, \mathrm{v} / \mathrm{v})$. A $0.9-\mathrm{mL}$ amount of the extract was placed in a 2.0-mL microtube and $0.1 \mathrm{~mL}$ of $1.0 \mathrm{~N} \mathrm{H}_{2} \mathrm{SO}_{4}$ was added to hydrolyze fructan to fructose. The mixed solution was boiled on a heat block at $100{ }^{\circ} \mathrm{C}$ for $15 \mathrm{~min}$, removed, and cooled to room temperature. The solution was neutralized with $0.1 \mathrm{~mL}$ of $1.0 \mathrm{~N}$ $\mathrm{NaOH}$. The reducing sugar derived from starch and fructan was measured using the previously described method. The TNC content represents the sum of all water-soluble sugars (i.e., glucose, fructose, and sucrose) and storage sugars (i.e., starch and fructan).

The experiment was arranged in a completely randomized block design with four replications. Treatment effects were determined by analysis of variance using the general linear model procedure of SAS (version 9.1; SAS Institute, Cary, NC). Significantly different means were separated by Fisher's protected least significant difference test at $P \leq 0.05$. The analysis of variance revealed an interaction among treatments and years, and therefore data are presented for each year.

\section{Results}

Photosynthesis ANd Respiration. Between 6 June and 24 July 2006, $P_{n}$ rate was similar among coring regimes (Table 1A) higher $\mathrm{P}_{\mathrm{n}}$ level was observed on 16 Aug. 2006 in spring plus summer versus noncored bentgrass, but was similar compared with spring-only cored bentgrass. On the final measurement date in 2006, bentgrass subjected to spring plus summer coring had a higher $\mathrm{P}_{\mathrm{n}}$ level compared with spring-only and noncored bentgrass. In 2007, $\mathrm{P}_{\mathrm{n}}$ levels were higher on 31 May and 24 July in spring plus summer versus noncored bentgrass, but were similar to spring-only cored bentgrass. No differences in $\mathrm{P}_{\mathrm{n}}$ were observed on 2 July and 14 Aug. 2007 among coring regimes. On 6 Sept. 2007, the $\mathrm{P}_{\mathrm{n}}$ level was higher in spring plus summer cored compared with spring-only cored bentgrass. However, the Pn level was similar between spring-only and noncored bentgrass at the time of the final measurement in 2007.

Respiration rates generally were similar among coring regimes in 2006 (Table 2). However, spring plus summer cored bentgrass exhibited a higher $\mathrm{R}_{\mathrm{W}}$ level on 6 June 2006 compared with noncored bentgrass. Respiration rate was greater on 16 Aug. 2006 in spring-only versus noncored bentgrass. Except on 31 May, no differences in $R_{w}$ were observed in 2007 among coring regimes. On 31 May 2007, spring plus summer cored bentgrass had a higher $\mathrm{R}_{\mathrm{w}}$ level compared with noncored bentgrass.

LEAF CARBOHYDRATES. In 2006, creeping bentgrass leaf tissue from plots subjected to spring plus summer coring had a greater level of WSC on 21 June compared with spring-only and noncored bentgrass (Table 3). On 21 July, WSC were greater in spring plus summer versus spring-only cored bentgrass. No significant differences in leaf WSC levels were observed on 25 May and 4 Aug. among coring treatments. Leaf WSC level was lower on 7 Sept. in spring plus summer and noncored bentgrass compared with spring-only cored bentgrass.

SC levels were greater on 25 May and 7 Sept., but similar on 4 Aug. for spring plus summer versus noncored bentgrass (Table 3). Spring plus summer cored bentgrass leaf tissues had lower SC levels on 21 June compared with spring-only and noncored bentgrass. SC levels were higher on 7 Sept. 2006 in spring-only and spring plus summer regimes compared with noncored bentgrass. Except on 21 July and 7 Sept., no differences in leaf TNC were observed among coring treatments. On 21 July, TNC levels were lower in spring-only cored bentgrass leaves versus noncored bentgrass. By 7 Sept. lowest TNC levels were found in bentgrass leaves from noncored plots.

Table 1. Photosynthesis in 'Providence' creeping bentgrass in response to spring-only coring (SP), spring plus summer coring (SP+SU), or no coring (N-C) in 2006 and 2007.

\begin{tabular}{|c|c|c|c|c|c|c|}
\hline \multirow[b]{3}{*}{ Treatments } & \multicolumn{6}{|c|}{ Photosynthesis $\left(\mu \mathrm{mol} \cdot \mathrm{s}^{-1} \cdot \mathrm{m}^{-2}\right)$} \\
\hline & \multicolumn{6}{|c|}{2006} \\
\hline & 6 June & 21 June & 7 July & 24 July & 16 Aug. & 7 Sept. \\
\hline $\mathrm{SP}^{\mathrm{z}}$ & $6.7 \mathrm{a}^{\mathrm{w}}$ & $8.4 \mathrm{a}$ & $4.6 \mathrm{a}$ & $4.1 \mathrm{a}$ & $4.8 \mathrm{ab}$ & $7.2 \mathrm{~b}$ \\
\hline \multirow[t]{2}{*}{$\mathrm{N}-\mathrm{C}^{\mathrm{x}}$} & $6.9 \mathrm{a}$ & $8.2 \mathrm{a}$ & $4.9 \mathrm{a}$ & $3.7 \mathrm{a}$ & $4.6 \mathrm{~b}$ & $7.3 \mathrm{~b}$ \\
\hline & \multicolumn{6}{|c|}{2007} \\
\hline $\mathrm{SP}+\mathrm{SU}$ & $7.0 \mathrm{a}$ & $6.4 \mathrm{a}$ & & & $6.9 \mathrm{a}$ & $5.4 \mathrm{a}$ \\
\hline $\mathrm{N}-\mathrm{C}$ & $4.6 \mathrm{~b}$ & $5.3 \mathrm{a}$ & & & $7.1 \mathrm{a}$ & $4.7 \mathrm{ab}$ \\
\hline
\end{tabular}

${ }^{\mathrm{z}}$ Spring-only (SP) coring was performed on 27 Apr. 2006 and 29 Apr. 2007.

${ }^{y}$ Spring plus summer (SP+SU) corings were performed on 27 Apr., 6 and 28 June, and 25 July 2006; and 29 Apr., 6 June, and 3 and 31 July 2007. ${ }^{\mathrm{x}}$ Non-cored (N-C) control.

${ }^{w}$ Means in a column in a given year followed by the same letter are not significantly different based on Fisher's protected least significant difference test at $P \leq 0.05$. 
Table 2. Respiration in 'Providence' creeping bentgrass in response to spring-only coring (SP), spring plus summer coring (SP+SU), and no coring (N-C) in 2006 and 2007.

\begin{tabular}{|c|c|c|c|c|c|c|}
\hline \multirow[b]{3}{*}{ Treatments } & \multicolumn{6}{|c|}{ Respiration $\left(\mu \mathrm{mol} \cdot \mathrm{s}^{-1} \cdot \mathrm{m}^{-2}\right)$} \\
\hline & \multicolumn{6}{|c|}{2006} \\
\hline & 6 June & 21 June & 7 July & 26 July & 16 Aug. & $7 \mathrm{Sept}$. \\
\hline $\mathrm{SP}^{\mathrm{z}}$ & $8.7 \mathrm{ab}^{\mathrm{w}}$ & $9.4 \mathrm{a}$ & $7.0 \mathrm{a}$ & $9.8 \mathrm{a}$ & $8.4 \mathrm{a}$ & $7.8 \mathrm{a}$ \\
\hline \multirow[t]{2}{*}{$\mathrm{N}-\mathrm{C}^{\mathrm{x}}$} & $8.0 \mathrm{~b}$ & $9.1 \mathrm{a}$ & $6.3 \mathrm{a}$ & $9.4 \mathrm{a}$ & $7.5 \mathrm{~b}$ & $8.0 \mathrm{a}$ \\
\hline & \multicolumn{6}{|c|}{2007} \\
\hline $\mathrm{SP}+\mathrm{SU}$ & $11.0 \mathrm{a}$ & $9.8 \mathrm{a}$ & & & $7.2 \mathrm{a}$ & $9.6 \mathrm{a}$ \\
\hline $\mathrm{N}-\mathrm{C}$ & $9.8 \mathrm{~b}$ & $10.0 \mathrm{a}$ & & & $8.8 \mathrm{a}$ & $10.3 \mathrm{a}$ \\
\hline
\end{tabular}

${ }^{\mathrm{z}}$ Spring-only (SP) coring was performed on 27 Apr. 2006 and 29 Apr. 2007.

${ }^{y}$ Spring plus summer (SP+SU) corings were performed on 27 Apr., 6 and 28 June, and 25 July 2006; and 29 Apr., 6 June, and 3 and 31 July 2007. ${ }^{\mathrm{x}}$ Non-cored $(\mathrm{N}-\mathrm{C})$ control.

${ }^{\text {w} M e a n s ~ i n ~ a ~ c o l u m n ~ f o r ~ e a c h ~ y e a r ~ f o l l o w e d ~ b y ~ t h e ~ s a m e ~ l e t t e r ~ a r e ~ n o t ~ s i g n i f i c a n t l y ~ d i f f e r e n t ~ b a s e d ~ o n ~ F i s h e r ' s ~ p r o t e c t e d ~ l e a s t ~ s i g n i f i c a n t ~ d i f f e r e n c e ~}$ test at $P \leq 0.05$.

Table 3. Water-soluble carbohydrate (WSC), storage carbohydrate (SC), and total nonstructural carbohydrate (TNC) in 'Providence' creeping bentgrass leaf tissue subjected to spring-only coring (SP), spring plus summer coring (SP+SU), or no coring (N-C) in 2006.

\begin{tabular}{|c|c|c|c|c|c|}
\hline \multirow[b]{2}{*}{ Treatments } & \multicolumn{5}{|c|}{2006} \\
\hline & 25 May & 21 June & 21 July & 4 Aug. & 7 Sept. \\
\hline & \multicolumn{5}{|c|}{ WSC [glucose $\left(\mathrm{mg} \cdot \mathrm{g}^{-1}\right.$ dry wt)] } \\
\hline $\mathrm{SP}^{\mathrm{z}}$ & $41.0 \mathrm{a}^{\mathrm{w}}$ & $45.3 \mathrm{~b}$ & $31.2 \mathrm{~b}$ & $51.4 \mathrm{a}$ & $37.6 \mathrm{a}$ \\
\hline \multirow[t]{2}{*}{$\mathrm{N}-\mathrm{C}^{\mathrm{x}}$} & $44.3 \mathrm{a}$ & $42.5 \mathrm{~b}$ & $32.9 \mathrm{ab}$ & $53.8 \mathrm{a}$ & $35.1 \mathrm{~b}$ \\
\hline & \multicolumn{5}{|c|}{$\mathrm{SC}$ [glucose (mg.g $\mathrm{g}^{-1}$ dry wt)] } \\
\hline SP & $58.4 \mathrm{ab}$ & $40.6 \mathrm{~b}$ & $26.4 \mathrm{~b}$ & $38.0 \mathrm{~b}$ & $44.8 \mathrm{a}$ \\
\hline \multirow[t]{2}{*}{$\mathrm{N}-\mathrm{C}$} & $56.3 \mathrm{~b}$ & $43.0 \mathrm{a}$ & $33.9 \mathrm{a}$ & $42.3 \mathrm{a}$ & $41.9 \mathrm{~b}$ \\
\hline & \multicolumn{5}{|c|}{ TNC [glucose (mg. $\mathrm{g}^{-1}$ dry wt)] } \\
\hline $\mathrm{SP}$ & $99.4 \mathrm{a}$ & $85.9 \mathrm{a}$ & $57.6 \mathrm{~b}$ & $89.4 \mathrm{a}$ & $82.4 \mathrm{a}$ \\
\hline $\mathrm{SP}+\mathrm{SU}$ & $101.6 \mathrm{a}$ & $88.7 \mathrm{a}$ & $62.9 \mathrm{ab}$ & $95.4 \mathrm{a}$ & $81.3 \mathrm{a}$ \\
\hline $\mathrm{N}-\mathrm{C}$ & $100.7 \mathrm{a}$ & $85.5 \mathrm{a}$ & $66.8 \mathrm{a}$ & $96.0 \mathrm{a}$ & $77.0 \mathrm{~b}$ \\
\hline
\end{tabular}

${ }^{\mathrm{z}}$ Spring-only (SP) coring was performed on 27 Apr. 2006.

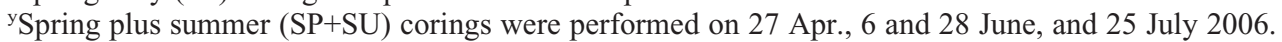

${ }^{\mathrm{x}}$ Non-cored $(\mathrm{N}-\mathrm{C})$ control.

"Means in a column for each carbohydrate parameter followed by the same letter are not significantly different based on Fisher's protected least significant difference test at $P \leq 0.05$.

In 2007, spring plus summer cored bentgrass tissue had a lower leaf WSC level on 17 July, but similar levels on 1 and 28 June, 15 Aug., and 6 Sept. when compared with noncored bentgrass (Table 4). Except on 6 Sept., leaves subjected to spring plus summer coring generally had similar WSC levels compared with spring-only cored bentgrass. On 6 Sept., leaf WSC levels were lower in spring plus summer versus springonly cored bentgrass. Leaf SC levels were lower on 1 June, similar on 28 June and 17 July, and higher on 15 Aug. and 6 Sept. for spring plus summer versus noncored bentgrass. Spring plus summer cored bentgrass had lower leaf SC levels on 1 June and 17 July, similar SC levels on 28 June, and higher leaf SC levels on 15 Aug. and 6 Sept. when compared with spring-only cored bentgrass tissues. TNC levels in leaves were similar on 1 June and 17 July, but greater on 28 June, 15 Aug., and 6 Sept. 2007 in spring plus summer cored compared with spring-only and noncored bentgrass.

ROOT CARBOHYDRATES. In 2006, spring plus summer cored bentgrass had higher root WSC levels on 25 May and 7 Sept. compared with noncored bentgrass (Table 5). No differences in root WSC levels were observed on the other three measurement dates between spring plus summer and noncored bentgrass. Root WSC levels were similar between 25 May and 4 Aug., but greater in spring plus summer versus spring-only cored bentgrass on 7 Sept. Similar root SC levels were observed on 25 May and 21 June among the three coring treatments. A lower root SC level was observed on 21 July in spring plus summer compared with spring-only and noncored bentgrass. Root SC levels were higher on 4 Aug. and 7 Sept. 2006 in spring plus summer versus spring-only and noncored bentgrass. Root TNC levels were similar on 25 May and 21 June, lower on 21 July, and higher on 4 Aug. and 7 Sept. in spring plus summer versus spring-only and noncored bentgrass.

In 2007, root WSC levels were similar among coring treatments on most measurement dates (Table 6). An exception was on 17 July, when spring plus summer cored bentgrass had a lower root WSC level versus spring-only and noncored bentgrass. Root SC levels were lower on 1 and 28 June, similar on 
Table 4. Water-soluble carbohydrate (WSC), storage carbohydrate (SC), and total nonstructural carbohydrate (TNC) in 'Providence' creeping bentgrass leaf tissue subjected to spring-only coring (SP), spring plus summer coring (SP+SU), or no coring (N-C) in 2007.

\begin{tabular}{|c|c|c|c|c|c|}
\hline \multirow[b]{2}{*}{ Treatments } & \multicolumn{5}{|c|}{2007} \\
\hline & 1 June & 28 June & 17 July & 15 Aug. & 6 Sept. \\
\hline & \multicolumn{5}{|c|}{ WSC [glucose $\left(\mathrm{mg} \cdot \mathrm{g}^{-1}\right.$ dry wt)] } \\
\hline $\mathrm{SP}^{\mathrm{z}}$ & $40.9 \mathrm{a}^{\mathrm{w}}$ & $40.5 \mathrm{a}$ & $27.1 \mathrm{ab}$ & $30.4 \mathrm{a}$ & $30.1 \mathrm{a}$ \\
\hline \multirow[t]{2}{*}{$\mathrm{N}-\mathrm{C}^{\mathrm{x}}$} & $40.5 \mathrm{a}$ & 39.9 a & $30.0 \mathrm{a}$ & $30.5 \mathrm{a}$ & $28.6 \mathrm{ab}$ \\
\hline & \multicolumn{5}{|c|}{ SC [glucose (mg.g $\mathrm{g}^{-1}$ dry wt)] } \\
\hline SP & $88.8 \mathrm{a}$ & $43.6 \mathrm{a}$ & $45.2 \mathrm{a}$ & $43.8 \mathrm{~b}$ & $36.2 \mathrm{~b}$ \\
\hline \multirow[t]{2}{*}{$\mathrm{N}-\mathrm{C}$} & $87.5 \mathrm{a}$ & $43.1 \mathrm{a}$ & $40.9 \mathrm{~b}$ & $45.3 \mathrm{~b}$ & $36.8 \mathrm{~b}$ \\
\hline & \multicolumn{5}{|c|}{ TNC [glucose (mg. $\mathrm{g}^{-1}$ dry wt)] } \\
\hline SP & $129.7 \mathrm{a}$ & $84.1 \mathrm{~b}$ & $71.3 \mathrm{a}$ & $74.2 \mathrm{~b}$ & $66.3 \mathrm{~b}$ \\
\hline $\mathrm{SP}+\mathrm{SU}$ & $117.8 \mathrm{a}$ & $85.4 \mathrm{a}$ & $67.3 \mathrm{a}$ & $80.1 \mathrm{a}$ & $67.0 \mathrm{a}$ \\
\hline $\mathrm{N}-\mathrm{C}$ & $128.0 \mathrm{a}$ & $83.0 \mathrm{~b}$ & $70.9 \mathrm{a}$ & $75.7 \mathrm{~b}$ & $65.4 \mathrm{~b}$ \\
\hline
\end{tabular}

${ }^{\mathrm{z}}$ Spring-only (SP) coring was performed on 29 Apr. 2007.

${ }^{y}$ Spring plus summer (SP+SU) corings were performed on 29 Apr., 6 June, and 3 and 31 July 2007.

${ }^{\mathrm{x}}$ Non-cored (N-C) control.

${ }^{w}$ Means in a column for each carbohydrate parameter followed by the same letter are not significantly different based on Fisher's protected least significant difference test at $P \leq 0.05$.

Table 5. Water-soluble carbohydrate (WSC), storage carbohydrate (SC), and total nonstructural carbohydrate (TNC) in 'Providence' creeping bentgrass root tissue from plots subjected to spring only coring (SP), spring plus summer coring (SP+SU), or no coring (N-C) in 2006 .

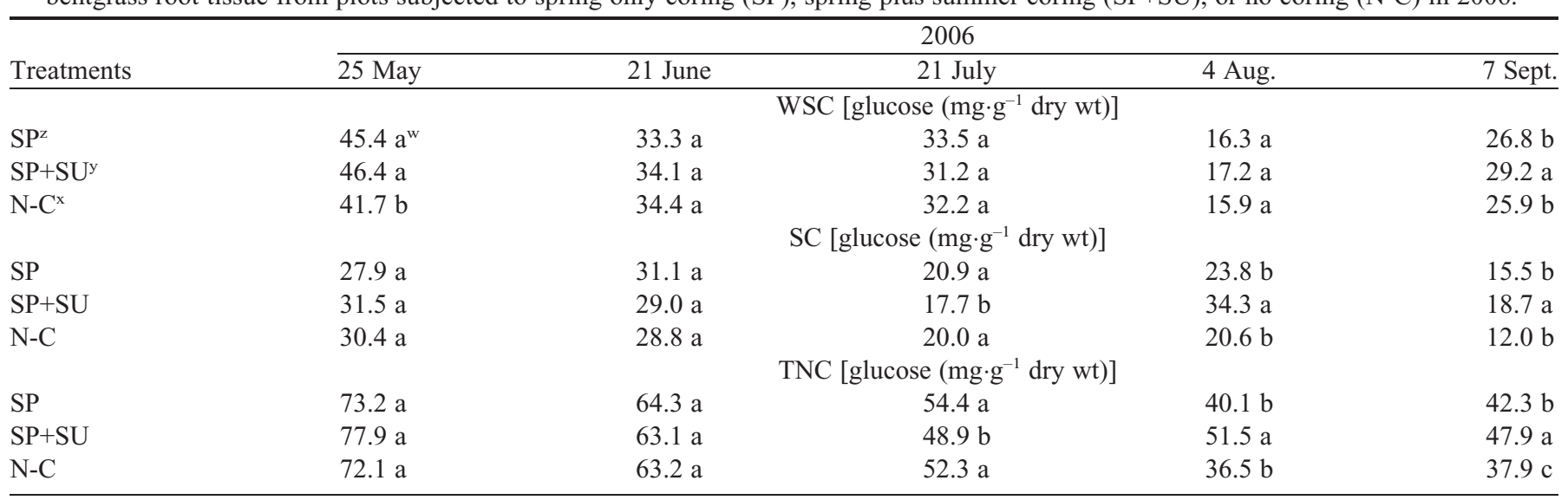

${ }^{\mathrm{z}}$ Spring-only (SP) coring was performed on 27 Apr. 2006.

${ }^{\mathrm{y}}$ Spring plus summer (SP+SU) corings were performed on 27 Apr., 6 and 28 June, and 25 July 2006.

${ }^{\mathrm{x}}$ Non-cored (N-C) control.

"Means in a column for each carbohydrate parameter followed by the same letter are not significantly different based on Fisher's protected least significant difference test at $P \leq 0.05$.

17 July and 15 Aug., and higher on 6 Sept. for spring plus summer cored versus noncored bentgrass. No differences in root SC were observed on all five measurement dates between spring plus summer cored and spring-only cored bentgrass. Root TNC levels were lower on 1 June and 17 July, similar on 28 June and 15 Aug., and higher on 6 Sept. in spring plus summer compared with noncored bentgrass. Creeping bentgrass roots subjected to spring plus summer coring had similar TNC levels on 1 and 28 June and 15 Aug., and lower TNC levels on 17 July versus spring-only cored bentgrass. On 6 Sept., TNC levels were higher in spring plus summer cored than in spring-only cored or noncored bentgrass.

\section{Discussion}

Data showed that $P_{n}$ levels generally were similar among the three treatments throughout the experimental periods in both years. Noncored bentgrass had lower $\mathrm{P}_{\mathrm{n}}$ levels versus spring plus summer cored bentgrass on only two dates in 2006 and 2007. However, on the final measurement date in early Sept. 2006 and 2007 (i.e., 37 to $42 \mathrm{~d}$ since last cored), $P_{n}$ was higher in spring plus summer cored than spring-only cored bentgrass. Coring in the spring, however, did impact $\mathrm{R}_{\mathrm{w}}$ on the initial measurement date in both years. On 6 June 2006 and 31 May 2007, $R_{W}$ was higher in spring plus summer cored versus noncored plots. Perhaps an increase in $\mathrm{R}_{\mathrm{w}}$ occurred at this time because creeping bentgrass growth would be more rapid earlier in the year versus in summer. It also is possible that the larger diameter tines used in spring created more injury, resulting in an increase in $\mathrm{R}_{\mathrm{w}}$. Thereafter, $\mathrm{R}_{\mathrm{w}}$ levels were similar among all coring regimes in both years. Hence, coring in general did not negatively impact $P_{n}$ or $R_{w}$. It should be noted again that $P_{n}$ and $\mathrm{R}_{\mathrm{W}}$ usually were measured between 9 and $33 \mathrm{~d}$ following coring. Therefore, injured creeping bentgrass plants probably 
Table 6. Water-soluble carbohydrate (WSC), storage carbohydrate (SC), and total nonstructural carbohydrate (TNC) in 'Providence' creeping bentgrass root tissue subjected to spring only coring (SP), spring plus summer coring (SP+SU), or no coring (N-C) in 2007.

\begin{tabular}{|c|c|c|c|c|c|}
\hline \multirow[b]{2}{*}{ Treatments } & \multicolumn{5}{|c|}{2007} \\
\hline & 1 June & 28 June & 17 July & 15 Aug. & 6 Sept. \\
\hline & \multicolumn{5}{|c|}{ WSC [glucose (mg. ${ }^{-1}$ dry wt)] } \\
\hline $\mathrm{SP}^{\mathrm{z}}$ & $22.2 \mathrm{a}^{\mathrm{w}}$ & $18.2 \mathrm{a}$ & $35.4 \mathrm{ab}$ & $36.5 \mathrm{a}$ & $34.4 \mathrm{a}$ \\
\hline $\mathrm{SP}+\mathrm{SU}^{\mathrm{y}}$ & $20.3 \mathrm{a}$ & $19.1 \mathrm{a}$ & $32.5 \mathrm{~b}$ & $38.0 \mathrm{a}$ & $36.9 \mathrm{a}$ \\
\hline \multirow[t]{2}{*}{$\mathrm{N}-\mathrm{C}^{\mathrm{x}}$} & $22.5 \mathrm{a}$ & $18.8 \mathrm{a}$ & $37.4 \mathrm{a}$ & $38.2 \mathrm{a}$ & $37.0 \mathrm{a}$ \\
\hline & \multicolumn{5}{|c|}{$\mathrm{SC}$ [glucose (mg.g $\mathrm{g}^{-1}$ dry wt)] } \\
\hline SP & $61.9 \mathrm{~b}$ & $38.1 \mathrm{ab}$ & $19.7 \mathrm{a}$ & $22.1 \mathrm{a}$ & $25.3 \mathrm{ab}$ \\
\hline $\mathrm{SP}+\mathrm{SU}$ & $67.2 \mathrm{~b}$ & $36.9 \mathrm{~b}$ & $18.2 \mathrm{a}$ & $20.0 \mathrm{a}$ & $27.0 \mathrm{a}$ \\
\hline \multirow[t]{2}{*}{$\mathrm{N}-\mathrm{C}$} & $73.8 \mathrm{a}$ & $40.3 \mathrm{a}$ & $19.2 \mathrm{a}$ & $21.9 \mathrm{a}$ & $22.2 \mathrm{~b}$ \\
\hline & \multicolumn{5}{|c|}{ TNC [glucose (mg.g ${ }^{-1}$ dry wt)] } \\
\hline SP & $84.1 \mathrm{~b}$ & $56.3 \mathrm{a}$ & $55.1 \mathrm{a}$ & $58.6 \mathrm{a}$ & $59.7 \mathrm{~b}$ \\
\hline $\mathrm{SP}+\mathrm{SU}$ & $87.5 \mathrm{~b}$ & $56.0 \mathrm{a}$ & $50.7 \mathrm{~b}$ & $58.0 \mathrm{a}$ & $63.9 \mathrm{a}$ \\
\hline $\mathrm{N}-\mathrm{C}$ & $96.3 \mathrm{a}$ & $59.0 \mathrm{a}$ & $56.6 \mathrm{a}$ & $60.1 \mathrm{a}$ & $59.2 \mathrm{~b}$ \\
\hline
\end{tabular}

${ }^{\mathrm{z}}$ Spring-only (SP) coring was performed on 29 Apr. 2007.

${ }^{\mathrm{y}}$ Spring plus summer (SP+SU) corings were performed on 29 Apr., 6 June, and 3 and 31 July 2007.

${ }^{\mathrm{x}}$ Non-cored $(\mathrm{N}-\mathrm{C})$ control.

${ }^{w}$ Means in a column for each carbohydrate parameter followed by the same letter are not significantly different based on Fisher's protected least significant difference test at $P \leq 0.05$.

had time to recover before measurements being obtained, resulting in similar $P_{n}$ and $R_{w}$ levels among treatments.

The rate of leaf and root regrowth following coring could depend on the availability of carbohydrates. Leaf carbohydrate levels were similar among rating dates and years. The highest levels of leaf carbohydrates were observed in spring at the time the first measurements were made in May or June. Leaf WSC levels in both years generally were lowest in July. Leaf WSC levels were higher in September in spring plus summer versus the other coring treatments in 2006, but not in 2007. Leaf TNC levels also were higher in September in spring plus summer cored compared noncored bentgrass in both years. Similarly, Narra et al. (2004) found that TNC levels in creeping bentgrass clippings decreased in mid-July and August, but increased during the autumn months. There are no other known studies with which to compare our results. Mowing causes mechanical injury and does impact leaf carbohydrate levels. For example, a reduction in fructans and glucose in leaves was reported in response to mowing (Howieson and Christians, 2008; Volenec, 1986). Howieson and Christians (2008) found that the duration and amount of fructan and glucose reduced was greatest in double-cut bentgrass. The aforementioned effects, however, were transient and leaf sugar levels were equivalent to those found in uncut bentgrass by $60 \mathrm{~h}$ following mowing. Narra et al. (2004) reported that TNC levels generally were higher in creeping bentgrass mowed to a height of $0.64 \mathrm{~cm}$ compared with 1.27 or $1.90 \mathrm{~cm}$. They explained these unexpected findings by suggesting that more sheath and stem tissues may have been inadvertently collected at the lower mowing height. Conversely, Davis and Dernoeden (1991) found that stems tissue collected from kentucky bluegrass (Poa pratensis L.) mowed to a height of $3.8 \mathrm{~cm}$ contained lower TNC levels than plants mowed to a height of $7.6 \mathrm{~cm}$.

Root TNC levels were highest in the spring and lowest in late summer. The summer decline of TNC levels in creeping bentgrass roots was previously reported by $\mathrm{Xu}$ and Huang (2003). WSC levels in roots were similar on most rating dates. An exception was in Sept. 2006, when root WSC levels were higher in spring plus summer cored versus spring-only cored and noncored bentgrass. SC and TNC root levels were highest in noncored bentgrass in June 2007 and root TNC levels were lowest in spring plus summer cored bentgrass in July 2006 and 2007. Otherwise, root carbohydrate levels were similar among coring treatments until September. Like leaves, TNC levels in roots were highest in May and June. Thereafter, TNC levels declined in 2006, but remained static in 2007. In September, root SC and TNC levels generally were higher in spring plus summer cored compared with spring-only and noncored bentgrass. Root SC levels were on average 56\% (2006) and 22\% (2007) higher in September of each year in spring plus summer cored compared with noncored bentgrass. Root TNC levels were $26 \%$ (2006) and 8\% (2007) higher in spring plus summer cored versus noncored bentgrass in September. Leaf tissue generally contained higher TNC levels than roots. A larger increase in TNC and SC levels, however, was observed in root versus leaf tissue in September. This suggested that spring plus summer coring resulted in a greater proportion of carbon being allocated to roots. Late-summer increases in TNC and SC levels associated with coring may have been due to improved nutrient (i.e., N) availability accorded by reincorporation of soil and topdressing or improved oxygen availability. Higher TNC levels in tissues of spring plus summer cored creeping bentgrass in September likely would enable plants to recover more rapidly from summer stresses in the autumn.

As previously noted, large diameter tines are preferred for coring greens in spring because the turf would be expected to recover more rapidly from injury at that time of year compared with summer (O'Brien and Hartwiger, 2003). The higher leaf and root TNC levels found in creeping bentgrass in spring would be useful in assisting the turf in recovering from injury caused by the more invasive, large diameter tines. However, lower TNC levels in summer indicated that using a larger tine at this time would have a greater negative effect on plant recovery. Hence, TNC data support the recommendation to use large diameter tines in spring and less invasive, small diameter tines in summer.

This study represents the seminal investigation of the effects of summer coring on $\mathrm{P}_{\mathrm{n}}, \mathrm{R}_{\mathrm{w}}$, and carbohydrate levels in leaves 
and roots of creeping bentgrass maintained under putting green conditions. As previously noted, little is known about the effects of mechanical injury on carbohydrate metabolism in turfgrasses. However, there are a plethora of cultural management practices imposed on golf greens, including topdressing, vertical cutting, water injection aeration, rolling, brushing etc. that can cause mechanical injury. Future research efforts should focus on the impact that other injurious cultural practices have on carbohydrate metabolism in creeping bentgrass golf greens.

\section{Literature Cited}

Amiard, V., A. Marvan-Bertran, J.P. Billard, C. Huault, and M.P. Prud'homme. 2003. Fate of fructose supplied to leaf sheaths after defoliation of Lolium perenne L.: Assessment by 13C-fructose labeling. J. Expt. Bot. 54:1231-1243.

Davis, D.B. and P.H. Dernoeden. 1991. Summer patch and kentucky bluegrass quality as influenced by cultural practices. Agron. J. 83:670-677.

Donaghy, D.J. and W.J. Fulkerson. 1998. Priority for allocation of water soluble carbohydrate reserves during regrowth of Lolium perenne. Grass Forage Sci. 53:211-218.

Fu, J., J. Fry, and B. Huang. 2007. Growth and carbon metabolism of tall fescue and zoysiagrass as affected by deficit irrigation. HortScience 42:378-381.

Howieson, M.J. and N.E. Christians. 2008. Carbohydrate metabolism and efficiency of photosystem II in mown creeping bentgrass (Agrostis stolonifera L.). HortScience 43:525-528.
McCarty, L.B. 2001. Best golf course management practices. Prentice Hall, Upper Saddle River, NJ.

Narra, S., T.W. Fermanian, J.M. Swiader, T.B. Voight, and B.E. Branham. 2004. Total nonstructural carbohydrate assessment in creeping bentgrass at different mowing heights. Crop Sci. 44:908913.

O'Brien, P. and C. Hartwiger. 2003. Aeration and topdressing for the 21st century. U.S. Golf Assn. Green Section Record 43(3):1-7.

Smith, D. 1972. Carbohydrate reserves of grasses, p. 318-333. In: V.B. Younger and C.M. McKell (eds.). The biology and utilization of grasses. Academic Press, New York.

Smith, D. 1981. Removing and analyzing total nonstructural carbohydrates from plant tissue. Wisconsin Agr. Expt. Sta. Res. Rpt. R2107.

Ting, S.V. 1956. Rapid calorimetric methods for simultaneous determination of total reducing sugars and fructose in citrus juices. J. Agr. Food Chem. 4:263-266.

U.S. Golf Association. 2004. USGA recommendations for a method of putting green construction. 11 June 2008. <http://www.usga.org/turf/ course_construction/green_article/putting_green_guidelines.htm $>$.

Volenec, J.J. 1986. Nonstructural carbohydrate in stem base components of tall fescue during regrowth. Crop Sci. 26:122-127.

Wang, K. and Y. Jiang. 2007. Waterlogging tolerance of kentucky bluegrass cultivars. HortScience 42:386-390.

$\mathrm{Xu}, \mathrm{Q}$. and B. Huang. 2000. Effects of differential air and soil temperature on carbohydrate metabolism in creeping bentgrass. Crop Sci. 40:1368-1374.

$\mathrm{Xu}, \mathrm{Q}$. and B. Huang. 2003. Seasonal changes in carbohydrate accumulation for two creeping bentgrass cultivars. Crop Sci. 43:266-271. 